\title{
Segmented Work, Race-Conscious Workers: Structure, Agency and Division in the CIO Era
}

\author{
THOMAS J. SUGRUE
}

Ex-Cell-O, a major machinery manufacturer in Detroit, was not a particularly hospitable place for black workers in the post-World War II years. The firm had a long-standing history of what officials of the National Association for the Advancement of Colored People (NAACP) called "flagrant job discrimination". Whole sections of the Ex-Cell-O plant were bastions of whiteness; black workers remained confined in the firm's most unpleasant and low-status jobs. Moreover, company hiring officials often turned away black job applicants. Responding to the systematic racial exclusion and subordination at Ex-Cell-O, leaders of United Automobile Workers (UAW) Local 49 called for nondiscriminatory hiring and upgrading at the firm. In 1950, Local 49 officers complained that Ex-Cell-O failed to promote a black worker to a position that he deserved under seniority rules. Under pressure, the machinery company's management promoted him "to a better job", but did little more.'

Complicating the picture, the white rank and file at Ex-Cell-O fiercely resisted racial integration. When a skilled black worker was offered a job in an all-white department in 1951, 146 of the 149 white workers walked out in a hate strike, and planned a work stoppage when they returned. Local 49 officials refused to support the strikers and insisted that the black worker keep his job. In the aftermath of the walkout, shop-floor race relations remained tense. The combination of company hiring policy and rank-and-file racism kept the doors at Ex-Cell-O virtually shut to blacks. More than a decade after the hate strike, the firm had barely improved its hiring practices, despite its promises to treat black and white workers equally. In 1962 black Ex-Cell-O workers complained that the company's managers "either overly place Negroes in certain classifications or pick one or two to place in different classes to say they don't discriminate". Ex-Cell-O's tokenism riled AfricanAmerican workers. One commented with chagrin that Ex-Cell-O promoted "the average white worker", but only upgraded blacks who were

'Executive Secretary's Report to the Executive Board of Directors, Detroit Branch NAACP, 8 September 1952, p. 2; National Association for the Advancement of Colored People Papers, Library of Congress, Washington, DC, Group II, Box C90, File: Detroit, Mich., July-Dec. 1952; Local 49 Shop Committee to Brother Oliver, n.d. [c. March-April 1950], and Malcolm Evans to William Oliver, 10 April 1950, United Automobile Workers, Local 49 Collection, Archives of Labor and Urban Affairs, Walter P. Reuther Ljbrary, Detroit, Michigan (hereafter ALUA).

International Review of Social History 41 (1996), pp. 389-406 
"exceptionally outstanding, above the white workers". He continued: "I deserve to be rated as any 'average' man, working with and being compared to 'average' men." At the peak of the civil rights era, white racial privileges remained firmly in place. ${ }^{2}$

In his important article "Class, Race and Democracy in the CIO", Bruce Nelson offers labor historians a powerful set of tools to interpret the racial segmentation of the workforce at firms like Ex-Cell-O. As Nelson suggests, Local 49 was divided between a job-conscious, racially conservative rank and file, which acted to preserve its racial advantages, and a somewhat more progressive union cadre, which supported the principle of civil rights in the workplace. As members of the UAW, Ex-Cell-O workers paid union dues, a portion of which funded organizations such as the NAACP. Under the leadership of Walter P. Reuther, the UAW contributed thousands of dollars to civil rights organizations, lobbied for fair employment practices legislation, and promoted integration in the workplace. But, even as their union leaders fought for anti-discrimination laws, Ex-Cell-O's white rank and file staunchly resisted attempts to break down the color line of labor. They engaged in spontaneous, militant protest - not as a weapon to further their class interests, but instead to maintain their racial privileges. ${ }^{3}$

That white workers in Detroit engaged in a hate strike in the early 1950 s may come as a surprise to some. But in the rapidly changing post-war city, racial tensions ran high, both in the workplace and in the community. As Nelson reminds us, "homeownership and a racialized commitment to family and neighborhood have been integral to the identity of working-class whites". Blacks and whites had few meaningful contacts in or outside of the workplace in 1950s-era Detroit. The vast majority of working Detroiters lived in neighborhoods that were strictly segregated by race. Nearly 90 per cent of whites and blacks would have had to move for there to be complete racial integration in the city. But as the city's black population expanded rapidly and as civil rights activists began agitating for racial equality, the existing racial order was threatened. Blacks who crossed Detroit's invisible boundaries of race faced a fate even worse than that of the single black worker who

2 "EXCELLO - Local 49 UAW-CIO", Report of H. Ross, 27 July 1951 in United Automobile Workers Fair Practices Department Collection, ALUA, Box 16, Folder 1623; letter [unidentified], 9 July 1956, ibid.; Complaint Against Excello Corporation, 1962, Detroit Urban League Papers (hereafter DUL), Michigan Historical Collections, Bentley Library, University of Michigan, Ann Arbor, Box 48, Folder A12-25.

3 On Walter P. Reuther and the UAW's racial policies, see Kevin Boyle, The UAW and the Heyday of American Liberalism (Ithaca, 1995). esp. pp. 107-131; Boyle, "There Are No Union Sorrows That the Union Can't Heal': The Struggle for Racial Equality in the United Automobile Workers, 1940-1960", Labor History, 36 (1995), pp. 5-23; Nelson Lichtenstein. The Most Dangerous Man in Detroit: Waher P. Reuther and the Fate of American Labor (New York, 1995), pp. 206-211, 315-317, 370-395. 
breached the color line at Ex-Cell-O. The city's black "pioneers", those who ventured across the city's racial frontier, faced the wrath of angry white neighbors. The first blacks to move onto a formerly all-white block were regularly greeted by angry picketers and vandals who besieged their houses, breaking windows and lighting fires. A survey of white Detroit $\mathrm{CIO}$ members conducted the same year as the Ex-Cell-O hate strike showed that only 18 per cent supported residential racial integration. And a majority of UAW members joined other white Detroiters in supporting conservative candidates for city council and mayor who pledged to preserve their neighborhoods' racial homogeneity. In such a climate of racial hostility, it is no surprise that the tensions of the community extended to the workplace. ${ }^{4}$

The myriad ways that working-class culture, on the shop floor and at home, limited the social democratic agenda of the CIO and of post-New Deal liberalism is a topic well worth greater research. Nelson opens up an avenue of inquiry that only a few twentieth-century labor historians have begun to follow, namely an examination of the ways that a raciallyexclusive, masculine working-class identity fostered racial divisions that eroded whatever "culture of unity", to borrow Lizabeth Cohen's phrase, might have existed in the CIO's early years. To be sure, the CIO was a close ally of black workers, an organization whose leaders were often deeply committed to an agenda of racial equality. And, as Nelson knows, the CIO was a remarkably open institution, at least by the standards of mid-twentieth-century America. At a time when blacks and whites lived thoroughly segregated lives (both North and South), the CIO supported black workers in a way that few other organizations did. At a time when blacks and whites worshipped in separate churches, bowled in different leagues, risked their dignity and sometimes their lives if they stepped into the wrong bar, and belonged to racially homogeneous fraternal societies, unions provided one of the few public spaces where blacks and whites interacted on anything more than a superficial level. But Nelson offers a sobering revision of this picture. However open the $\mathrm{CIO}$ was, unity was a seldom-met ideal. Building upon the best recent

4 For other examples of hate strikes in the auto industry after World War II, see Boyle, "There Are No Sorrows That the Union Cannot Heal", pp. 15-16, 18, 21. For a discussion of race, homeownership and politics in post-war Detroit, see Thomas J. Sugrue, "Crabgrass-Roots Politics: Race, Rights, and the Reaction Against Liberalism in the Urban North, 1940-1964". Journal of American History, 82 (1995), pp. 551-578. On rates of residential segregation in Detroit, see Karl E. Taeuber and Alma F. Taeuber, Negroes in Cities: Residential Segregation and Neighborhood Change (Chicago, 1965), p. 39; for CIO members' attitudes on integration, see Arthur Komhauser, Detroit as the People See It: A Survey of Attitudes in an Industrial City (Detroit, 1952), p. 91. On patterns of racial segregation generally, see Arnold R. Hirsch, "With or Without Jim Crow: Black Residential Segregation in the United States", in Arnold R. Hirsch and Raymond A. Mohl (eds.), Urban Policy in Twentieth-Century America (New Brunswick, NJ, 1993), pp. 65-99. 
scholarship on race relations, he shows how white CIO workers defended separate seniority lines, trapped blacks in unskilled jobs, and weakened their unions' commitment to civil rights.

Nelson's most important - and perhaps most controversial finding - is that rank-and-file workers constrained the civil rights liberalism of the union cadre. By synthesizing a number of recent studies and drawing from his own pathbreaking research, he challenges a cherished assumption that rank-and-file activism was a progressive force that was smothered by conservative business unionism. In Nelson's telling, the post-war "social compact" and anti-communism were not as important as deeply entrenched white racism in limiting the social democratic possibilities of the CIO. The failure of Operation Dixie and the persistence of the Dixie-GOP coalition in national politics was the natural consequence of the actions of white workers who wanted to maintain their racial privileges. Even northern workers, widely assumed to be the bulwark of the "liberal consensus", rallied against civil rights policies that threatened the racial status quo. northern white workers adopted a version of the not-in-mybackyard attitude toward racial equality. It was acceptable to mandate legal equality in the South as long as policies did not interfere with the racial division of labor and "homeowners' rights" in the North.

Nelson's call for the systematic study of the ways that white racism impoverished industrial unionism is a useful point of departure for future

5 Lizabeth Cohen, Making a New Deal: Industrial Workers in Chicago, 1919-1939 (New York, 1989). On the routine segregation of blacks and whites in the North, see Thomas J. Sugrue, The Origins of the Urban Crisis: Race and Inequality in Postwar Detroit (Princeton, 1996), chs 2, 8 and 9; Amold R. Hirsch, Making the Second Ghetto: Race and Housing in Chicago, 1940-1960 (Cambridge, 1983); on religious institutions, see John T. McGreevy, Parish Boundaries: The Catholic Encounter with Race in the TwentiethCentury North (Chicago, 1996). On the CIO and blacks in the North, see August Meier and Elliot Rudwick, Black Detroit and the Rise of the UAW (New York, 1979). On the CIO in the South, see Michael K. Honey, Southern Labor and Black Civil Rights: Organizing Memphis Workers (Urbana, 1993); for an excellent overview, see Rick Halpern, "Organized Labor, Black Workers, and the Twentieth-Century South: The Emerging Revision", in Melvyn Stokes and Rick Halpern (eds), Race and Class in the American South Since 1890 (Oxford and Providence, 1992), pp. 43-76; on the parallels between the $\mathrm{CIO}$ in the North and South, see Robert Korstad and Nelson Lichtenstein, "Opportunities Found and Lost: Labor Radicals and the Early Civil Rights Movement", Journal of American History, 75 (1988), pp. 786-811. See also Michael Goldfield, "Race and the CIO: Possibilities for Racial Egalitarianism During the 1930s and 1940s", International Labor and Working-Class History, 44 (1993), pp. 1-32. The piece should be read in conjunction with the critical responses to it by Gary Gerstle, Robert Korstad, Marshall Stevenson and Judith Stein, in ibid., pp. 33-63.

- On the North, Nelson confirms other findings about the deep-rooted resistance of northern working-class whites to liberal civil rights measures. See Sugrue, "Crabgrass-Roots Politics", esp. pp. 562-578; Arnold R. Hirsch, "Massive Resistance in the Urban North: Trumbull Park, Chicago, 1953-1966", Journal of American History, 82 (1995), pp. 522550. See also Gary Gerstle, "Race and the Myth of the Liberal Consensus", ibid., pp. 579580. 
histories of the CIO. Nelson correctly notes that the "attitudes and behaviors of the majority of workers" reinforced racial hierarchies. Subsequent historians of industrial workers and their unions will tell incomplete, indeed distorted stories, if they fail to account for the persistence of working-class whiteness. But running through Nelson's article is another theme, one that, if highlighted, greatly complicates our story of race and democracy in the CIO. What is clear is how little labor historians still know about interactions of race, class and unionism in the mid-twentieth century. Nelson's case studies (dock workers in Mobile, Mexican and black longshoremen in San Pedro, steelworkers in Youngstown, autoworkers in Detroit, tobacco workers in Winston-Salem, transit workers in New York) show that race, ethnicity and gender played out in very different ways in different places at different times. What emerges from Nelson's article, above all, is evidence of the varieties of racial discrimination and accommodation. At mid-century, definitions of race were up for grabs. Racial practices were in tremendous flux. The outcome - for black and white workers alike - was unpredictable. In such a fluid environment, blacks (and their white allies) pushed hard against the color line, and whites resisted fiercely.

Following Nelson's example, we need to be attentive to the diversity of racial practices, from union to union, from workplace to workplace, and from community to community. If we take as our starting-point the argument (advanced most persuasively by Barbara Jeanne Fields) that race is not a transhistorical constant or a timeless verity, but rather that it is constructed, the product of historical contingency, then we need to examine the multiple manifestations of racism. Because of Nelson's intervention, twentieth-century labor historians can move their agenda beyond the question of "was there workplace racism?" (to which Nelson answers a resounding yes) to the richer inquiry of what forms racial prejudice took, why it was sometimes robust and at other times insignificant. We need to examine the still-underexplored links between racial divisions in the workplace and white working-class culture, values and ideology, attentive to the important distinction that Eric Arnesen has highlighted between racial beliefs and racial practices. So many important questions remain unanswered. Why did some employers open their gates to African Americans? Why did some unions resist and others reluctantly support workplace integration? Why, sometimes in the same plants, were blacks excluded from whole job classifications, while they worked side-by-side on other jobs? If we agree with Nelson that many workers shared deep-seated prejudices against African Americans, why did some work peacefully with blacks, while others fiercely battled civil rights? ${ }^{7}$

7 Barbara Jeanne Fields, "Ideology and Race in American History", in J. Morgan Kousser and James M. McPherson (eds), Region, Race, and Reconstruction: Essays in Honor of C. Vann Woodward (New York, 1982), pp. 143-177. See also Evelyn Brooks Higginbotham, "African-American Women's History and the Metalanguage of Race", Signs, 17 (1992), 
Nelson's answers to these questions are clearly informed by the recent fusion of labor history and cultural history, especially in the work of David Roediger, Alexander Saxton and Noel Ignatiev, who have teased out a history of the formation of a white identity from extremely reticent nineteenth-century sources. ${ }^{8}$ Nelson, however, wears the influence of cultural history lightly, endorsing other scholars' imaginative reconstructions of working-class whiteness, but not attempting to offer a twentiethcentury version of their work. Like Roediger, Nelson avoids the pitfall of returning to the stale debate over whether labor historians have "privileged" class over race. He shows that race and class are not polar opposites. Rather they are fundamentally imbricated. Workers develop class consciousness and racial identities simultaneously. ${ }^{9}$ Building on this insight, Nelson challenges romantic evocations of working-class community and solidarity, yet does not jettison the notion of class altogether. Race, he argues, "calls into question one of the most essential premises of the new labor history - namely its belief in the emergent reality of one working class [. . .]". Nelson does not, however, go as far as Michael Kazin, who controversially argued that American workers saw themselves as "a people rather than a class". Rather, following the work of such African-American historians as Joe William Trotter, $\mathrm{Jr}$ and Earl Lewis, Nelson suggests the existence of parallel, racialized class consciousnesses. ${ }^{10}$ Race in this formulation does not "trump" class; rather

pp. 251-274; Eric Amesen, “'Like Banquo's Ghost, It Will Not Down': The Race Question and the American Railroad Brotherhoods, 1880-1920", American Historical Review, 99 (1994), pp. 1601-1633, esp. p. 1606.

David Roediger, The Wages of Whiteness: Race and the American Working Class (London, 1991); idem, Towards the Abolition of Whiteness (London, 1994); Alexander Saxton. The Rise and Fall of the White Republic: Class Politics and Mass Culture in the Nineteenth Century (New York, 1990); Noel Ignatiev, How the Irish Became White (New York and London, 1995). Their approach owes much to literary studies and cultural anthropology. See, among many others, Bell Hooks, Black Looks: Race and Representation (London, 1992); Toni Morrison, Playing in the Dark: Whiteness and the Literary Imagination (Cambridge, MA, 1992); Ruth Frankenberg, White Women, Race Matters: The Social Construction of Whiteness (Minneapolis, 1993).

- Compare Nelson with David Roediger, "Race and the Working-Class Past in the United States: Multiple Identities and the Future of Labor History". Intermational Review of Social History, 38 (1993), Supplement, pp. 127-143. The Hill-Gutman debate, which has been replayed ad nauseam, needs no elaboration here. The debate was sparked by two articles: Herbert Hill, "Myth-Making as Labor History: Herbert Gutman and the United Mine Workers of America", International Joumal of Politics, Culure, and Society, 2:2 (Winter 1988), pp. 132-198; and idem, "Race, Ethnicity, and Organized Labor: The Opposition to Affirmative Action", New Politics, new ser., 1 (1987), pp. 32-182 and responses.

10 Michael Kazin, "A People Not a Class: Rethinking the Political Language of the Modern U.S. Labor Movement", in Mike Davis and Mfichael Sprinker (eds), Reshaping the U.S. Left: Popular Struggles in the 1980s (London, 1988), pp. 257-286; Earl Lewis, In Their Own Imteress: Race, Class, and Power in Twentieth-Century Norfolk, Virginia 
it complicates the process of class formation. Finally, again building on a central theme of the new labor history, Nelson emphasizes working-class agency. In his view, the segmentation of the workplace by race, ethnicity and gender are not inevitable consequences of impersonal forces. Rather, the subordination of women, blacks and other minorities in the workplace was the result of notions of race and gender that were constructed, reinforced, contested and challenged by black and white workers themselves.

Each of these propositions will undoubtedly generate intense and fruitful debate. The heart of Nelson's argument - the one most in need of refinement - is his emphasis on the agency of workers to explain persistent racial divisions in the workplace. Nelson (like Roediger and many other new labor historians), overemphasizes the ability of white workers to shape or contest the segmented labor market. And he overlooks the power of capital in shaping patterns of discrimination. While Nelson offers an extraordinarily rich account of the consequences of working-class racism, one that is borne out in much of my own research, his account could benefit from closer attention to the ways that working-class racism was structured by forces over which workers had varying degrees of control. Workers shaped their definitions of race and gender in a larger context, one in which their choices, their language, and their actions were circumscribed. Delimiting workers' agency was the power of employers, the structures of markets, and the prevailing political discourse. To emphasize the limits of worker agency is not to subscribe to deterministic economic models that leave workers out. But the story of the racial fragmentation of the workforce cannot end with the story of working-class racism. Sixteen years ago, David Montgomery offered a largely unheeded lament about "the paucity of economic analysis in recent writings on labor history". In the study of race and labor, Montgomery's lament is particularly germane. Historians need to pay more heed to the behavior of firms, the organization of production and the structure of the economy. We need to move beyond the false dichotomy between structure and agency, to consider the interaction of labor market forces, employers' choices, and workers' culture. Only then will the story of the racial fragmentation of the working class be complete. ${ }^{11}$

To build his case for the centrality of workers' agency, Nelson dismisses economic explanations of labor market segmentation. The straw man is sociologist Oliver Cox, who simplistically evoked employers' use of race

(Berkeley, 1991); Joe William Trotter, Jr, Coal, Class, and Color: Blacks in Southern West Virginia, 1915-1932 (Urbana, 1990).

"David Montgomery, "To Study the People: The American Working Class", Labor History, 21 (1980), p. 492 . One work that is particularly attentive to employers' practices and worker agency - is Honey, Southern Labor and Black Civil Rights, esp. pp. 13-43. 
as a "divide and conquer" strategy. Cox stands in for a whole generation of materialist scholars who simply explained away white racism. "Somehow," Nelson ascerbically writes, "according to this view, agency - and responsibility - always lay with forces external to the working class, and working people were either bullied into submission or duped into denying their true class interests." Nelson is right that Cox and other traditional Marxists suppressed the sordid history of working-class racism in favor of a reductionist view of capitalist power. Since the 1970s, however, the social scientific literature on workforce segmentation has left behind Cox's simple formulations. But Nelson ignores the many sociologists, economists and historians who have offered sophisticated explanations of the role that employers played in dividing their workforces by race and gender. And he traces the development of working-class consciousness without fully accounting for the demographic and economic forces that shaped labor markets and kept blacks and women confined in the worst, lowest-paying jobs. ${ }^{12}$

For the last twenty-five years, labor economists and sociologists have developed a rich theoretical literature on labor market segmentation. These structuralists (and here I deliberately lump together a range of scholars whose theoretical positions vary quite considerably) include David Gordon, Richard Edwards, Michael Reich, Michael Piore, Peter Doeringer, Kathryn Neckerman, Joleen Kirschenmann and Suzanne Model. Their work deserves the close attention of labor historians concerned with racial and gender inequalities in the workplace. No single model adequately explains the nature of labor force segmentation; but elements of each suggest directions for future historical research. Gordon, Edwards and Reich focus on the concentration of minority and women workers in "subordinate primary sector" and "secondary sector" jobs, arguing that the existence of a black labor surplus in major cities seriously constrained minority opportunities. ${ }^{13}$ Piore and Doeringer turn their sights to firms' internal labor markets, where managers seek shortterm profits by minimizing the costs of hiring and training new workers and fostering a sense of loyalty among workers. ${ }^{14}$ Neckerman and Kirsch-

12 Oliver Cromwell Cox, Caste, Class, and Race: A Study in Social Dynamics (New York, 1970).

13 Richard Edwards, Michael Reich and David M. Gordon, Labor Market Segmentation (Boston, 1975); Richard Edwards, Contested Terrain: The Transformation of the Workplace in the Twentieth Century (New York, 1979); Michael Reich, Racial Inequality: A PoliticalEconomic Analysis (Princeton, 1981); David M. Gordon, Richard Edwards and Michael Reich, Segmented Work, Divided Workers: The Historical Transformation of Labor in the United States (Cambridge, 1982). My own research suggests that their categorization of firms is too simple: many "secondary sector" firms, like construction, did not hire minorities; many primary sector firms, like the automobile industry, did. Employment patterns varied widely from firm to firm in each sector. See Sugrue, Origins of the Urban Crisis, ch. 4.

14 Peter Doeringer and Michael Piore, Internal Labor Markets and Manpower Analysis (Lexington, MA, 1971). 
enmann examine the ways that employers - often relying on a mix of experience and racial stereotyping - use race as a signal of undesirable workforce characteristics such as unreliability and lack of motivation. ${ }^{15}$ And Model traces the development of "ethnic niches", as an economic strategy adapted by immigrants, often without reference to race, that advanced one group's opportunities at the expense of another. What all of these approaches share, despite their significant theoretical differences, is attention to company hiring policies and the structures of labor markets that constrain or expand the opportunities of blacks, ethnic minorities and women. ${ }^{16}$

Labor historians have ignored these structuralist approaches much to the detriment of the field. In part, labor market economists have remained marginal to history because their sweeping generalizations seldom stand up to close historical scrutiny. But the primary reason that structuralist explanations remain on the margins of labor history has to do with the tendency of the last generation of labor historians to focus on workers' agency, on the actions of workers at the point of production and in their communities to resist the control, regimentation and dehumanization of modern industrial capitalism. The structuralists, in contrast, tend to view workers as powerless. Their emphasis on macroeconomic forces and internal labor market dynamics does not mesh with the prevailing emphasis in labor history on community, solidarity and, above all, working-class culture, ideology and identity. ${ }^{17}$

Nelson's approach offers an implicit rejoinder to the sterile determinism that characterizes the work of many labor economists and sociologists. But it also misses an opportunity to engage some of their most interesting ideas. If the structuralists' answers are often incomplete or even wrong, it does not follow that their questions are also flawed. It is too easy to denounce the work of labor economists and sociologists without grappling with the fundamental challenge they offer to labor history. Yes, they cram messy historical realities into neat theoretical

is Joleen M. Kirschenman and Kathryn M. Neckerman, "We'd Love to Hire Them But . . .: The Meaning of Race for Employers", in Christopher Jencks and Paul Peterson (eds), The Urban Underclass (Washington, 1991), pp. 203-232.

${ }^{16}$ Suzanne A. Model, "The Ethnic Niche and the Structure of Opportunity: Immigrants and Minorities in New York City", in Michael B. Katz (ed.), The "Underclass" Debate: Views from History (Princeton, 1993), pp. 161-193. Nelson uses Model's approach fruitfully in his discussion of Mexican-American longshore workers in California.

17 One of the most perceptive reviews of Gordon, Edwards and Reich, Segmented Work, Divided Workers, noted that "the authors assume that the job is the only place where people develop ideas about work", and they fail "to acknowledge the importance of culture, ideology, and politics in working-class history". Ronald Schatz, "Labor Historians, Labor Economics, and the Question of Synthesis", Journal of American History, 71 (1984), p. 99. For a equally pointed criticism of the labor economists" "neglect of the cultural and ideological aspects of workers" lives", see Michael Kazin, "Struggling with the Class Struggle", Labor History, 28 (1987), pp. 507-508. 
boxes. But whatever the empirical deficiencies of structural approaches to labor market segmentation (and they are legion), they challenge labor historians to look at old evidence afresh and to fashion a synthetic approach that situates working-class culture and identity in a macroeconomic context. Without greater attention to structure, our understanding of labor will remain incomplete.

There are a handful of studies of labor market segmentation that point the way to a fruitful synthesis of structure and agency. The best example of a work built on the theoretical base of labor market economics, but deeply rooted in primary source research, is Ruth Milkman's pathbreaking Gender at Work. Through a sophisticated study of the fate of women workers in the automobile and electronics industries during World War II, Milkman offers a powerful explanation of the rise and persistence of gender discrimination, tracing its roots in the work rules, seniority practices and division of labor in the industry. Milkman rejects the determinism of labor market theorists, "stressing instead the historically specific economic, political and social factors that shape patterns of employment by sex", and, I would add, race. For Milkman, the dynamics of workplace segmentation were shaped by an industry's location in the primary or secondary sectors (those with secure, high-paying jobs or those with contingent, poorly-paying jobs), by the available supply and cost of different groups of workers, and by the reaction of existing workers to new hiring. Especially important for Milkman were the conditions "operative when that industry's labor market forms". An industry's patterns of hiring by race and sex "quickly gains all the weight of tradition and becomes extraordinarily inflexible". Milkman does not leave unions and workers out of her story. But she is also fully aware of the limitations of worker agency. Unions could reinforce patterns of workplace segmentation, but bound by the rules that they had played a role in creating, they found it extraordinarily difficult to change entrenched patterns. Employers were reluctant to challenge the division of labor in workplaces; workers and their unions made it their role to defend established work rules, departmental divisions and seniority. ${ }^{18}$

With a structural approach in mind, I will offer an extension of Nelson's arguments, building on his description of racial conflict in the workplace, appreciative of the need to excavate the hidden histories of working-class racial conflict, but also bringing in the missing dimension of capitalism and labor markets, and examining the ways that worker agency was limited by and interacted with structural forces. The first question is: why do employers discriminate? Labor economists, by and

18 Ruth Milkman, Gender at Work: The Dynamics of Job Segregation by Sex during World War II (Urbana, 1987); see also idem, "Rosie the Riveter Revisited: Management's Postwar Purge of Women Automobile Workers", in Nelson Lichtenstein and Stephen Meyer (eds), On the Line: Essays in the History of Auto Work (Urbana, 1989), pp. 129 152. 
large, start with the ahistorical assumption that employer behavior is utterly predictable, and that patterns of racial segmentation must then also be predictable. But an examination of the historical record reveals a story of far greater complexity. At times, employers - reinforcing the racial beliefs and prejudices of their workers - used race as a strategy (sometimes unsuccessfully because of bi-racial and interracial solidarity) to thwart union organization drives. In the pre-World War II North and in the Jim Crow South, employers evoked fears of "social equality" to pit racially-conscious white workers against blacks. The use of blacks as strikebreakers in auto plants in Depression-era Detroit, in the tobacco and furniture plants of Memphis, and in early twentieth-century Pittsburgh's steel industry, to offer but three examples, provides abundant evidence of the importance of the divide and conquer strategy in employers' anti-union arsenal. ${ }^{19}$

Over the course of the twentieth century, a growing number of industrialists began hiring black workers for reasons that moved beyond the "divide and conquer" strategy. During World War II, for example, the convergence of African-American activism, wartime anti-fascist and pluralist rhetoric, and federal intervention opened many jobs to African Americans for the first time, often against the will of white employers. But many other firms began hiring blacks out of pure self-interest, to maximize profits by taking advantage of the precarious position of blacks in the labor market. Perhaps the most important change during the $\mathrm{CIO}$ era was the dramatic transformation in the racial composition of urban, industrial labor markets, the consequence of the massive migration of African Americans to southern cities, and particularly to the urban North. Because blacks had migrated from low-wage areas and because industrial jobs were often better-paying than anything they had left behind, employers could easily channel black newcomers into the lowestpaying jobs. Black workers who had experienced discrimination in the past were more likely to accept jobs that white workers, with a wider range of employment options, would summarily reject. In addition, historic patterns of racial exclusion created a surplus of black labor. Because blacks were wholly excluded from certain jobs (the building trades, skilled labor, sales work), employers who did decide to hire blacks could select the best workers, place them in jobs for which they were overqualified, and pay them relatively less. In their study of Ford, Thomas Maloney and Warren Whatley have found that the auto giant, one of the largest employers of blacks in the North, took advantage of the surplus of black labor to hire an aristocracy of African-American

\footnotetext{
${ }^{29}$ Examples of employers' use of blacks as strikebreakers abound. For a few examples, see Meier and Rudwick, Black Detroit and the Rise of the UAW, ch. 2, esp. pp. 69-71, 87-97; Honey, Southem Labor and Black Civil Rights, pp. 246-247, 260-263; Dennis C. Dickerson, Out of the Crucible: Black Steelworkers in Western Pennsylvania (Albany, 1983), pp. 8-10, 13-17, 85-93.
} 
laborers - married men, older than the average automobile worker, and thus more likely to remain as stable, long-term employees. ${ }^{20}$

Employers, like workers, held a variety of racial beliefs and acted on them in different ways. Some were motivated by pure racial stereotypes to place blacks in the hardest, most dangerous jobs. Managers also sometimes decided that certain jobs were black jobs, based on the assumption that blacks were singularly capable of the most physically demanding work. (In a similar way, employers sex-typed jobs, hiring women to do work, like sewing or making electrical components, for which they were "naturally" suited.) One Detroit Chrysler official hired only blacks to work in the dangerous paint room. He explained his rationale: "Yes, some jobs white folks will not do; so they have to take niggers in, particularly in duce work, spraying paint on car bodies. This soon kills a white man." Asked if it killed blacks, he responded, "It shortens their lives, it cuts them down but they're just niggers."21 Still other employers, dipping into another murky pool of racial stereotypes, viewed blacks as lazy, shiftless and irresponsible, thus rationalizing their decision to hire whites only. At the hiring gate, faced with a choice between equally qualified blacks and whites, corporate hiring officials frequently turned blacks away. ${ }^{22}$

Not all employer decisions were based on racial stereotypes, though they might have racially exclusionary consequences. For example, many employers (in the steel, chemical and machine tool industries, to name three) regularly relied on worker references. Drawing workers from a single group - whether co-ethnics, parishioners at the same church, or groups of relatives - offered considerable advantages to employers. Most importantly, they minimized the costs of hiring, built worker loyalty and tied workers to networks that facilitated social control. In steel, for example, whole sections of plants were dominated by a single ethnic group. To be sure, nepotism and ethnic niches usually resulted in the exclusion of minorities, who were seldom members of the institutions churches, fraternal organizations, ethnic clubs - that were the basis of niche recruitment. And, because of the intense and enduring taboo against interracial marriage, firms that gave preference to the sons, brothers and cousins of employees rarely, if ever, brought in blacks. In

Thomas N. Maloney and Warren C. Whatley, "Making the Effort: The Contours of Racial Discrimination in Detroit's Labor Markets, 1920-1940", Journal of Economic History, 55 (1995), pp. 465-493. National Urban League Department of Research, "Observations of Conditions Among Negroes in the Fields of Education, Recreation and Employment in Selected Areas of the City of Detroit, Michigan", June 1941, pp. 35-36, in DUL, Box 74, Folder: History.

${ }^{21}$ Quoted in B.J. Widick, "Black Workers: Double Discontents", in idem (ed.), Auto Work and Its Discontents (Baltimore, 1976), p. 54.

2 For examples, see Conversations with "BIG THREE" (Motor Industry) Vice Presidents in Charge of Personnel, Detroit, 29 September 1943, in "Survey of Racial and Religious Conflicts in Detroit", Civil Rights Congress of Michigan Collection, ALUA, Box 71. 
such cases, employers and workers - enmeshed in a society-wide structure of racial discrimination - could at once claim that they were not racist, while they perpetuated the absolute exclusion of blacks from whole sections of plants. ${ }^{23}$

Employers also practiced racial discrimination as a means of maintaining shop-floor morale and discipline. They pandered to the racial prejudices of white workers to prevent debilitating walkouts or protests. Here the agency of workers did shape the discriminatory practices of employers. To take one example, management feared (quite realistically) that breaking the color line would provoke hate strikes and bring production to a halt. A Detroit worker perceptively noted in 1940 that "[i]f Walter P. Chrysler wanted to put a Negro on a good job he could order it done, but the white workers would make it so unpleasant that he wouldn't last [. . . ] Mr Chrysler isn't going to close the plant down for one Negro [...] or even for a few hundred Negroes". Employers weighed the advantages of hiring black workers against the disadvantages of disruptive protest on the shop floor and often capitulated to the demands of the majority of workers. ${ }^{24}$

The actions of employers and the state of labor markets, then, structured the opportunities of black workers in fundamental ways. But Nelson still poses an important question: could the CIO unions have done anything to alter firms' discriminatory practices? If there had been a solidaristic, fully integrated labor movement with civil rights as its primary goal, would it have mattered? Could blacks and whites "unite and fight" to alter corporation-driven discrimination? The answer is complicated. In the post-war industrial order, many unions (some Leftled unions and, notably, the skilled trades excepted) had very little power over corporate hiring policies. In the post-war years, managerial prerogative in hiring was sacrosanct. The National Labor Relations Board and the courts established firm precedents for the inviolability of the right of managers to hire whom they pleased. Attempts by unionists to exert control at the hiring gate were often thwarted as an improper infringement on managerial rights. The result was that the structures of racial discrimination were deeply resistant to change from the shop floor. Unions could kick and scream about racial disparities in hiring. Sometimes their pressure (particularly during the civil rights era) led companies to modify their hiring practices, though usually in a token way. But

${ }^{23}$ Model, "Ethnic Niches and the Structure of Opportunity", esp. pp. 161-193.

${ }^{24}$ Quote from Boyle, “'There Are No Sorrows That The Union Can't Heal'", p. 9. On hate strikes, see for example. Meier and Rudwick, Black Detroit and the Rise of the UAW, pp. 125-136; Lloyd Bailer, "Automobile Unions and Negro Labor", Political Science Quarterly, 59 (1944), pp. 568-575; Bruce Nelson, "Organized Labor and the Struggle for Black Equality in Mobile During World War II", Journal of American History, 80 (1993), pp. 952-988; and George Lipsitz, Rainbow at Mfidnight: Labor and Culture in the 1940s (Urbana, 1994), pp. 69-95. 
again and again unions' attempts to have a say over corporate hiring decisions had little effect. In the auto industry throughout the 1940s and 1950s, for example, the Big Three consistently rebuffed UAW proposals for anti-discrimination clauses in contracts. And business leaders staunchly resisted even the most tepid Fair Employment Practices laws. ${ }^{25}$ It would take the extraordinary intervention of the state (which the CIO staunchly supported), first through relatively ineffective state-level fair employment practices laws, then through national civil rights legislation, affirmative action and litigation, to make even a small dent in corporate hiring policies. ${ }^{26}$

In their domain - the shop floor - unions had a greater degree of control over the day-to-day lives of workers. CIO rank and file, stewards and union officials had the power to intervene to assist in the promotion of black workers, to break down separate seniority lines, to respond quickly and fairly to black workers' discrimination-related grievances, and to include blacks in union leadership positions. Here Nelson's argument holds sway, with an important qualification: employers also had great control over the day-to-day operations of plants; foreman and managers had varying degrees of discretion to upgrade blacks and redefine job classifications to eliminate racial divisions. They also controlled the racial composition of their workforces in another way: by choosing to locate plants in areas with racially homogeneous labor markets. Beginning on a wide scale in the 1940s, a growing number of firms moved operations out of increasingly black inner cities to predominantly white suburbs and small towns, where shop-floor civil rights became a moot point. ${ }^{27}$

25 Walter P. Reuther contended that the UAW "spent some of the most precious hours of our collective bargaining time" pushing for a fair employment clause. See Testimony of Walter P. Reuther, Hearings Held in Detroit, Michigan, December 14-15, 1960 (Washington, 1961), pp. 42, 57. See also George Robinson, Oral History, pp. 1-2, Blacks in the Labor Movement Collection, ALUA. Many African-American unionists and Communists criticized Reuther for not pushing harder for an anti-discrimination clause. See George Crockett, Oral History, pp. 28-29, ibid. For a case of a CIO union that maintained control over the hiring hall, see Nancy Quam-Wickham, "Who Controls the Hiring Hall?: The Struggle for Job Control in the ILWU during World War II", in Steve Rosswurm (ed.), The CIO's Left-Led Unions (New Brunswick, 1992). For examples of employer resistance to fair practices laws, see George Fulton to Albert Cobo, 27 October 1951, Mayor's Papers (1951), Burton Historical Collections, Detroit Public Library, Box 4, Folder: FEPC, DPL; Benson Ford to Walter P. Reuther, in United Automobile Worker (May 1953).

${ }_{26}$ On the limitations of state FEP laws, see George Schermer, "Effectiveness of Equal Opportunity Legislation", in Herbert R. Northrup and Richard L. Rowan (eds), The Negro and Employment Opportunity: Problems and Practices (Ann Arbor, 1965), pp. 7475, 79-81; for a discussion of the Michigan law, see Sugnue, Origins of the Urban Crisis, ch. 6.

27 At General Motors, the GM-UAW contract gave foremen discretion in the promotion and transfer of workers, allowing management's shop-floor representatives the power to discriminate by race. See Lichtenstein, The Most Dangerous Man in Detroit, p. 374. On 
Nelson's argument is most persuasive when applied to the skilled trades where unions had a tremendous say over the hiring process. In the crafts, unions and management usually had joint control over admission into apprenticeship programs and promotion. Thus workers served as gatekeepers (or co-gatekeepers) to the highest-paying, most prestigious jobs. And here they maintained the color line with brutal effectiveness. Their civil rights record was abysmal: they kept blacks out. To take one example, only 67 out of 11,125 skilled General Motors workers in 1960 were black. GM's practices were not atypical. The number of non-white crafts workers varied in other CIO-organized industries in the early 1960s: from 5.3 per cent in steel (whose workforce was 12.5 per cent black); to 1.5 per cent in tire manufacturing (whose workforce was 8.6 per cent black.) In 1960, only 2,005 of 86,966 apprentices nationwide were black. Moreover, virtually no women could be found in the fraternity of the crafts. The leadership of even the most progressive unions (like the UAW and the USWA) was reluctant to stand up to the skilled workers, who often threatened to rebel, and whose militancy was vital to union success. Civil rights activists and union insurgents alike butted heads against the impermeable racial walls of the crafts. It took federal intervention, through affirmative action and federal lawsuits, finally to crack open a small window of opportunity for black and women apprentices and journey persons. ${ }^{28}$

Workers and capitalists thus both shared responsibility for patterns of racial discrimination. Yet, in the current historiography on race relations and labor, employers are almost entirely missing. Capitalists held disproportionate power over their workers; they decided whom to hire, whom to promote, and whom to fire. Unions challenged corporations - sometimes successfully. But the story of labor in the post-war United States is one of limited power. In the aftermath of World War II, the CIO, as Nelson Lichtenstein has argued, "tied its fate more closely to that

decentralization, see Thomas J. Sugrue, "Forget About Your Inalienable Right to Work: Deindustrialization and its Discontents at Ford, 1950-1953", International Labor and Working-Class History, 48 (1995), pp. 112-130; George Sternlieb and James W. Hughes (eds), Post-Industrial America: Metropolitan Decline and Inter-Regional Job Shifts (New Brunswick, 1975).

3s GM figures from UAW data submitted to Hearings, pp. 63-65; for the number of black and women crafts workers in the steel industry, see Herbert Northrup et al., Negro Employment in Basic Industry: A Study of Racial Policies in Six Industries (Philadelphia, 1970), p. 287; in tire manufacturing, ibid., p. 428; for overall apprenticeship figures in all trades) see Ray Marshall and Vernon M. Briggs, Jr, The Negro and Apprenticeship (Baltimore, 1967), p. 28. The representation of women in all sectors of the auto industry and electronic industry (with the exception of sex-typed jobs and pink-collar work) grew gradually in the 1960 s and 1970s. See Milkman, Gender at Work, pp. 153-160. See also "NAACP Study Concerning Trade Union Apprenticeship" (prepared by Herbert Hill), 1960. National Association for the Advancement of Colored People Papers, Library of Congress, Washington, DC, Group III, Box A180, Folder: Labor: Apprenticeship Training. 
of industry and moved away from a strategy that sought to use union power to demand structural changes in the political economy". At the same time, an increasingly powerful business lobby battered unions with the rhetoric of free enterprise. Congress weakened trade unions through the Taft-Hartley Act. Anti-communists smothered the voices of labor's left wing. Federal courts regularly sided with big business. In such a climate, the pursuit of racial economic equality was extraordinarily diffcult. Rank-and-file racial prejudice was an important obstacle to workingclass unity, but by no means the only one. ${ }^{29}$

This brings us back, finally, to the Ex-Cell-O case. To best explain the events at the troubled Detroit firm, we need to combine Nelson's emphasis on working-class racism with an account of the company's management policies and their socio-economic context. Blacks retained a second-class status in Ex-Cell-O because white workers jealously guarded the wages of their whiteness, and because their employer took full advantage of a racially segmented workforce. White workers could think whatever they wanted about blacks, but, as the events at Ex-Cell-O made clear, the power to hire rested firmly in the hands of company managers.

Ex-Cell-O company officials had little incentive to hire blacks for well-paying jobs. In the 1950s Detroit had a surplus of black labor. The black unemployment rate was nearly double that of whites. And many of Ex-Cell-O's competitors systematically refused to hire blacks. Until Michigan passed the state FEPC law in 1955, it was common practice for firms to place race-specific job orders with the Michigan Employment Security Commission (MESC). The year of the Ex-Cell-O strike, 55.5 per cent of MESC job listings "were closed to non-whites by written specifications". Through the mid-1950s, local newspapers regularly included racial designations in want ads. ${ }^{30}$

\$Nelson Lichtenstein, "From Corporatism to Collective Bargaining: Organized Labor and the Eclipse of Social Democracy in the Postwar Era", in Steve Fraser and Gary Gerstle (eds), The Rise and Fall of the New Deal Order, 1930-1980 (Princeton, 1989), pp. 122-152, quote p. 133; Rosswurm. The ClO's Lefi-Led Unions; Elizabeth A. FonesWolf, Selling Free Enterprise: The Business Assault on Labor and Liberalism, 1945-1960 (Urbana, 1994).

30 City of Detroit, Mayor's Interracial Committee, "Racial Discrimination in Employment and Proposed Fair Employment Measures, A Report to the Common Council", 7 December 1951, p. 6, in Detroit Commission on Community Relations Collection, ALUA, Part I. Series 1, Box 11; "Michigan State Employment Service Experiences in the Placement of Minority Group Workers"; see also Detroit Focus, December 1951, in DUL, Box 21, Folder 21-14; Memorandum from the Michigan Committee on Civil Rights to the Governor's Committee on Civil Rights, 29 December 1948, in Vertical File - Pre 1960, ALUA, Box 4, Folder: Fair Employment Practices, Michigan, 1940s; for other examples, see "Discriminatory Job Orders Placed With State Employment Offices by Chrysler Corporation", 6 December 1954, in Francis Kornegay Papers, MHC. Box 4, Folder 124; UAW Local 600, Executive Board Minutes, 14 February 1950, in UAW Local 600 Papers, ALUA, Box 2. For similar patterns in Philadelphia, see Walter Licht, Getting Work: Philadelphia 18\$0-1950 (Cambridge, MA, 1993), pp. 125-126, 136-139. 
The economic situation of blacks took a turn for the worse, just as Michigan's civil rights law forced companies to stop designating jobs by race. Detroit, like other older industrial centers, was wrenched by a profound economic transformation in the 1950s. Detroit lost tens of thousands of jobs, even as the city's working-age black population continued to grow. Companies (like Ex-Cell-O, which built six new plants in all-white towns in rural Ohio and Indiana in the 1950s and none in Detroit) reduced their Detroit-area workforces through automation and attrition. Blacks, who were the newest entrants to the city's labor force and often unprotected by seniority, were disproportionately thrown into the ranks of the unemployed. Young, unskilled blacks had a difficult time finding even entry-level manufacturing jobs. In 1960, over 18 per cent of blacks were unemployed (more than double the percentage of whites); 41 per cent of black men eighteen years old and not in school were jobless (almost three times the percentage of eighteen-year-old whites). ${ }^{31}$

Ex-Cell-O's decision to upgrade token blacks was, likely, rooted in several considerations. It was partly an attempt by the company to minimize growing black discontent (even if, over the long run, it was unsuccessful). Black Ex-Cell-O workers had taken their complaints to the NAACP and the Urban League, both of which pressured the firm to hire more blacks. In the civil rights era, publicity-conscious northern firms often wished to avoid the taint of racism. More importantly, Ex-Cell-O's tokenism was a response to the intensely parochial shop-floor culture of the firm's white skilled workers. Just as employers were loath to upset the traditional hierarchies of gender in the auto and electrical industries, so too were employers reluctant to upset shop-floor traditions regarding race. Here, worker agency (following Nelson) and the firm's short-term interest in preserving the morale of white workers were inseparable. The hate strike in 1951 was a graphic reminder to Ex-Cell-O managers of the risks of tinkering with shop-floor customs. White workers defended a division of labor that ensured their racial privilege, while corporate executives, fearful of provoking hate strikes, maintained the racial status quo. ${ }^{32}$

The story of Ex-Cell-O illustrates in microcosm the complex causes of the segmentation of the post-war working class. It demonstrates the

"H.G. Bixby, President of Ex-Cell-O, "How Shall We Produce a More Favorable Climate for Business, Industry, and Payrolls in Detroit and Michigan". Speech before the Economic Club of Detroit, 18 April 1960, copy in Frances Kornegay Papers, Michigan Historical Collections, Bentley Library, University of Michigan, Ann Arbor, Box 8, Folder 265. On unemployment rates in 1960, see United States Bureau of the Census, United Stotes Census of Population, Detroit, Michigan and Adjacent Area, Final Report, PC1-24C, Tables 73 and 77. On youth unemployment, see "Detroit Metropolitan Area Employment by Age, Sex, Color, and Residence", in Detroit Branch NAACP Papers, ALUA, Part II, Box 10, Folder 10-5.

${ }_{32}$ Milkman, Gender at Work; on NAACP and Urban League campaigns to pressure employers to open jobs for blacks, see Sugrue, Origins of the Urban Crisis, ch. 6. 
need to consider the interwoven histories of working-class culture, economic and demographic forces, and corporate policy. The inequalities of race, ethnicity and gender remained so intractable precisely because they were mutually reinforcing. Bruce Nelson has offered an ambitious research agenda for future scholarship on race and labor, one that labor historians must heed. But it can be even more ambitious. Attention to both structure and agency provides a way to come to a fuller understanding of working-class division, one that goes beyond the limitations of the new labor history's overemphasis on agency and the labor economists' deterministic theoretical models. An analysis of the dynamics of discrimination - to the wages and profits of whiteness, and how they limited mid-twentieth-century struggles for justice - can make sense out of the still unresolved dilemma of inequality in modern America. 